\title{
Manta-like planktivorous sharks in Late Cretaceous oceans
}

Romain Vullo ${ }^{1 *}$, Eberhard Frey², Christina Ifrim³ ${ }^{3}$, Margarito A. González González ${ }^{4}$, Eva S. Stinnesbeck ${ }^{5}$ and Wolfgang Stinnesbeck ${ }^{6}$

${ }^{1}$ Univ Rennes, CNRS, Géosciences Rennes, UMR 6118, Rennes, France.

${ }^{2}$ Staatliches Museum für Naturkunde Karlsruhe, Karlsruhe, Germany.

${ }^{3}$ SNSB - Jura-Museum, Willibaldsburg, Eichstätt, Germany.

${ }^{4}$ Independent Researcher, Sabinas Hidalgo, Nuevo León, Mexico.

${ }^{5}$ Steinmann-Institut für Geologie, Mineralogie und Paläontologie, Rheinische FriedrichWilhelms-Universität, Bonn, Germany.

${ }^{6}$ Institute für Geowissenschaften, Ruprecht-Karls-Universität, Heidelberg, Germany. *Correspondence to: romain.vullo@univ-rennes1.fr

\begin{abstract}
:
The ecomorphological diversity of extinct elasmobranchs is incompletely known. Here, we describe Aquilolamna milarcae, a bizarre probable planktivorous shark from early Late Cretaceous open marine deposits in Mexico. Aquilolamna, tentatively assigned to Lamniformes, is characterized by hypertrophied, slender pectoral fins. This previously unknown body plan represents an unexpected evolutionary experimentation with underwater flight among sharks, more than 30 million years before the rise of manta and devil rays (Mobulidae), and shows that winglike pectoral fins have evolved independently in two distantly related clades of filter-feeding elasmobranchs. This newly described group of highly specialized long-winged sharks (Aquilolamnidae) displays an aquilopelagic-like
\end{abstract}


ecomorphotype and may have occupied, in late Mesozoic seas, the ecological niche filled by mobulids and other batoids after the Cretaceous-Paleogene boundary.

Elasmobranchs — the group of cartilaginous fishes including sharks, skates, and rays —are a successful group of ecomorphologically diverse cartilaginous fishes that first appeared around 380 million years ago, during the Late Devonian period (1). Modern plankton-feeding elasmobranchs are represented by two main ecomorphotypes corresponding, on one hand, to the whale shark (Rhincodontidae), the basking shark (Cetorhinidae) and the megamouth shark (Megachasmidae) (i.e., a macroceanic-tachypelagic morphotype characterized by a large fusiform body) and, on the other hand, to manta and devil rays (Mobulidae) (i.e., an aquilopelagic morphotype characterized by a dorsoventrally flattened body and winglike pectoral fins with a narrowly angular shape) (1-3). Whereas the former ecomorphotype convergently evolved during the Mesozoic in giant pachycormid bony fishes (4), the latter ecomorphotype has not been identified so far in the pre-Cenozoic fossil record $(3,5,6)$. We report here a new, bizarre fossil shark showing a previously unknown bauplan and morphological features indicative of filter-feeding habits. This complete specimen from the early Late Cretaceous (Turonian) of Mexico offers important insights into the Mesozoic evolution of medium- to largesized planktivorous fishes and the rise of "winged" pelagic elasmobranchs, long before the Paleogene origin and opportunistic radiation of mobulid rays (4-6).

Aquilolamna milarcae gen. et sp. nov. (formal taxonomic description is provided in the supplementary materials; Figs. 1 and 2 and figs. S3 to S6) stands out among both living and fossil elasmobranchs, with a body plan characterized by the acquisition of unusually hypertrophied pectoral fins combined with the persistence of a powerful tail showing a well- 
developed caudal fin (mosaic evolution). Among selachimorphs (modern sharks), narrow, distally expanded bladelike pectoral fins are known in various macroceanic sharks $(1,7)$, but these predatory (e.g., Isurus paucus and Carcharhinus longimanus) or planktivorous (e.g., Megachasma pelagios) forms are less specialized than Aquilolamna. Another notable feature of Aquilolamna is its apparent lack of dorsal and pelvic fins, although a taphonomic cause cannot be ruled out. Among neoselachians (modern elasmobranchs), dorsal fins are absent in the enigmatic Early Jurassic eel-shaped shark Ostenoselache (8) as well as in various rajiform and myliobatiform rays $(9,10)$. The assumed dorsal fin secondary loss (or reduction) in Aquilolamna could be interpreted as a direct consequence of the acquisition of hypertrophied pectoral fins. In contrast, pelvic fins were lost only in a few extinct chondrichthyan taxa, including eugeneodontiforms (10) and possibly Squatinactis, a small-sized Paleozoic cladodont shark with enlarged pectoral fins (11).

Aquilolamna is tentatively assigned to Lamniformes (mackerel sharks) on the basis of features such as the radial asterospondylic-type vertebrae (12) and the caudal fin skeleton showing a high hypochordal ray angle (i.e., ventrally directed hypochordal rays) (13). The discovery of Aquilolamna provides further insight into the Late Cretaceous diversification of neoselachians $(14,15)$ and likely represents another example of the ecomorphological plasticity and disparity of lamniform sharks, a group that appeared during the Early Cretaceous and today comprises mainly highly autapomorphic taxa that share relatively few synapomorphies (16-18). Living lamniforms show an impressive variety of morphologies, habitats, behaviors, and diets, with forms ranging from filter-feeders (Cetorhinidae and Megachasmidae) to top predators (Lamnidae) $(1,16,17)$. Aquilolamnids would reinforce the view that lamniforms achieved high 
levels of ecomorphological disparity precociously in their evolutionary history, as early as the mid-Cretaceous $(15,18,19)$.

The overall morphology and peculiar features of Aquilolamna (i.e., broad head with wide and near-terminal mouth, dentition most likely consisting of minute teeth, wing-shaped pectoral fins; see supplementary materials) strongly suggest that this shark was a suspension feeder, more closely related to the aquilopelagic than to the macroceanic-tachypelagic ecomorphotype category (Fig. 3 and figs. S10 and S11). Aquilolamna was probably a relatively slow swimmer, comparable to other suspension-feeding elasmobranchs (20). The long and slender pectoral fins of Aquilolamna most likely acted as stabilizers, but they may also have been used for propulsion by slow flapping movements. In addition, Aquilolamna had a typical, well-developed heterocercal caudal fin, similar to that of most macroceanic sharks (e.g., Megachasma) (1). Therefore, Aquilolamna probably used a combination of axial-based undulation and pectoral-finbased oscillation for its locomotion, with main thrust generated by the caudal fin and pectoral fins activated for increasing speed and for maneuvering. This contrasts with the strict pectoral fin-based locomotion of modern suspension-feeding aquilopelagic forms (i.e., mobulids), which are characterized by powerful enlarged pectoral fins (broad-based "wings" used for propulsion by oscillation) and a whiplike tail $(21,22)$. Among neoselachians, the combination of axial and pectoral locomotion is known only in guitarfishes (Rhinopristiformes) and some electric rays (Torpediniformes) $(21,22)$; however, these batoids are undulatory appendage propulsors (21, 22), unlike Aquilolamna.

The skeleton-based genus Aquilolamna may correspond to the enigmatic tooth-based genus Cretomanta (fig. S9), known from the Late Cretaceous (Cenomanian-Maastrichtian) of North America and North Africa (6). Cretomanta is especially common in the Eagle Ford Group 
of Texas (23), a lateral equivalent of the Agua Nueva Formation that yielded the holotype of Aquilolamna milarcae (figs. S1 and S9). Cretomanta is characterized by simple, minute hooked teeth (less than $2 \mathrm{~mm}$ high) that are indicative of planktivory, like teeth of manta rays and whale and basking sharks. Cretomanta was originally described as an early member of Mobulidae (24) and subsequently regarded as a possible planktivorous lamniform shark $(19,25)$. The microstructure of Cretomanta teeth, characterized by the presence of parallel-bundled and tangled-bundled enameloid layers typical of selachimorphs, strongly favours the latter hypothesis (26). The interpretation of Cretomanta as a suspension-feeding lamniform is consistent with the taxonomic and trophic positions proposed here for Aquilolamna. Therefore, we tentatively assign the genus Cretomanta to Aquilolamnidae. Platylithophycus from the Niobrara Chalk (27) is another mysterious Late Cretaceous (Coniacian-Campanian) genus that might also belong to Aquilolamnidae. On the basis of a single incomplete specimen consisting of gill arches and associated cartilage fragments, Platylithophycus was recently recognized as a large, possible filter-feeding elasmobranch of uncertain affinities, characterized by the presence of gill rakers of unusual morphology (27). A third putative Late Cretaceous plankton-feeding shark is the toothbased genus Pseudomegachasma, a lamniform restricted to the Cenomanian and interpreted as a specialized sand tiger shark (Odontaspididae) (28). Given its tooth morphology and systematic placement, it can be reasonably assumed that Pseudomegachasma had an Odontaspis-like or Megachasma-like general appearance, clearly distinct from that of Aquilolamna.

Late Cretaceous aquilolamnid sharks (Aquilolamna and possibly Cretomanta and Platylithophycus) and giant suspension-feeding pachycormid bony fishes (Bonnerichthys and Rhinconichthys) (4) may have been directly affected by the severe end-Cretaceous extinction of calcifying planktonic organisms resulting from an extreme acidification of surface oceans (29- 
31). Aquilolamnids and giant pachycormids all became extinct at the Cretaceous-Paleogene ( $\mathrm{K}-$ Pg) event and were ecologically replaced during the early Paleogene (Paleocene) by pelagic planktivorous batoids (Archaeomanta, Sulcidens, and the stem mobulid Burnhamia) (4-6) and rhincodontid sharks (Palaeorhincodon) (4), respectively (Fig. 4). The discovery of aquilolamnids suggests that the guild of large filter-feeding fishes changed in composition but not in structure after the end-Cretaceous mass extinction event, with both aquilopelagic and macroceanictachypelagic convergent forms being represented in pre- and post-K-Pg open marine ecosystems.

\section{References and Notes:}

1. L. J. V. Compagno, Alternative life-history styles of cartilaginous fishes in time and space. Environ. Biol. Fishes 28, 33-75 (1990).

2. L. J. V. Compagno, "Pelagic elasmobranch diversity" in Sharks of the Open Ocean: Biology, Fisheries and Conservation, M. D. Camhi, E. K. Pikitch, E. A. Babcock, Eds. (Blackwell, 2008), pp. 14-23.

3. C. Pimiento, J. L. Cantalapiedra, K. Shimada, D. J. Field, J. B. Smaers, Evolutionary pathways toward gigantism in sharks and rays. Evolution 73, 588-599 (2019).

4. M. Friedman, K. Shimada, L. D. Martin, M. J. Everhart, J. Liston, A. Maltese, M. Triebold, 100-million-year dynasty of giant planktivorous bony fishes in the Mesozoic seas. Science 327, 990-993 (2010).

5. C. J. Underwood, M. A. Kolmann, D. J. Ward, Paleogene origin of planktivory in the Batoidea. J. Vertebr. Paleontol. 37, e1293068 (2017). 
6. S. Adnet, H. Cappetta, G. Guinot, G. Notarbartolo di Sciara, Evolutionary history of the devilrays (Chondrichthyes: Myliobatiformes) from fossil and morphological inference. Zool. J. Linn. Soc. 166, 132-159 (2012).

7. T. Tomita, S. Tanaka, K. Sato, K. Nakaya, Pectoral fin of the megamouth shark: skeletal and muscular systems, skin histology, and functional morphology. PLoS ONE 9, e86205 (2014).

8. C. J. Duffin, Ostenoselache stenosoma n. g. n. sp., a new neoselachian shark from the Sinemurian (Early Jurassic) of Osteno (Lombardy, Italy). Pal. Lomb. N. Ser. 9, 3-27 (1998).

9. L. J. V. Compagno, Phyletic relationships of living sharks and rays. Am. Zool. 17, 303-322 (1977).

10. O. Larouche, M. Zelditch, R. Cloutier, Fin modules: an evolutionary perspective on appendage disparity in basal vertebrates. BMC Biol. 15, 32 (2017).

11. R. Lund, R. Zangerl, Squatinactis caudispinatus, a new elasmobranch from the Upper Mississippian of Montana. Ann. Carnegie Mus. 45, 43-55 (1974).

12. E. G. White, Interrelationships of the elasmobranchs with a key to the order Galea. Bull. Am. Mus. Nat. Hist. 74, 25-138 (1937).

13. S. H. Kim, K. Shimada, C. K. Rigsby, Anatomy and evolution of heterocercal tail in lamniform sharks. Anat. Rec. 296, 433-442 (2013).

14. C. J. Underwood, Diversification of the Neoselachii (Chondrichthyes) during the Jurassic and Cretaceous. Palaeobiology 32, 215-235 (2006).

15. G. Guinot, L. Cavin, 'Fish' (Actinopterygii and Elasmobranchii) diversification patterns through deep time. Biol. Rev. 91, 950-981 (2016). 
16. L. J. V. Compagno, Relationships of the megamouth shark, Megachasma pelagios (Lamniformes: Megachasmidae), with comments on its feeding habits. NOAA Tech. Rep. NMFS 90, 357-379 (1990).

17. L. J. V. Compagno, Sharks of the world. An annotated and illustrated catalogue of shark species known to date. Volume 2. Bullhead, mackerel and carpet sharks (Heterodontiformes, Lamniformes and Orectolobiformes). FAO Species Catalogue for Fishery Purposes 1, 1-269 (2001).

18. R. Vullo, G. Guinot, G. Barbe, The first articulated specimen of the Cretaceous mackerel shark Haimirichia amonensis gen. nov. (Haimirichiidae fam. nov.) reveals a novel ecomorphological adaptation within the Lamniformes (Elasmobranchii). J. Syst. Pal. 14, 1003-1024 (2016).

19. F. L. Condamine, J. Romieu, G. Guinot, Climate cooling and clade competition likely drove the decline of lamniform sharks. Proc. Natl. Acad. Sci. USA 116, 20584-20590 (2019).

20. D. W. Sims, Filter-feeding and cruising swimming speeds of basking sharks compared with optimal models: they filter-feed slower than predicted for their size. J. Exp. Mar. Biol. Ecol. 249, 65-76 (2000).

21. L. J. Rosenberger, Pectoral fin locomotion in batoid fishes: undulation versus oscillation. $J$. Exp. Biol. 204, 379-394 (2001).

22. C. A. D. Wilga, G. V. Lauder, "Biomechanics of locomotion in sharks, rays, and chimeras" in Biology of Sharks and Their Relatives, J. C. Carrier, J. A. Musick, M. R. Heithaus, Eds. (CRC Press, 2004), pp. 139-164.

23. B. J. Welton, R. F. Farish, The Collector's Guide to Fossil Sharks and Rays from the Cretaceous of Texas (Before Time, 1993). 
24. G. R. Case, T. T. Tokaryk, D. Baird, Selachians from the Niobrara Formation of the Upper Cretaceous (Coniacian) of Carrot River, Saskatchewan, Canada. Can. J. Earth Sci. 27, 10841094 (1990).

25. A. Noubhani, H. Cappetta, Les Orectolobiformes, Carcharhiniformes et Myliobatiformes (Elasmobranchii, Neoselachii) des Bassins à phosphate du Maroc (Maastrichtien-Lutétien basal). Palaeo Ichthyologica 8, 1-327 (1997).

26. S. Enault, H. Cappetta, S. Adnet, Simplification of the enameloid microstructure of large stingrays (Chondrichthyes: Myliobatiformes): a functional approach. Zool. J. Linn. Soc. 169, 144-155 (2013).

27. A. W. Bronson, J. G. Maisey, Resolving the identity of Platylithophycus, an enigmatic fossil from the Niobrara Chalk (Upper Cretaceous, Coniacian-Campanian). J. Paleontol. 92, 743750 (2018).

28. K. Shimada, E. V. Popov, M. Siversson, B. J. Welton, D. J. Long, A new clade of putative plankton-feeding sharks from the Upper Cretaceous of Russia and the United States. $J$. Vertebr. Paleontol. 35, e98135 (2015).

29. L. Alegret, E. Thomas, K. C. Lohmann, End-Cretaceous marine mass extinction not caused by productivity collapse. Proc. Natl. Acad. Sci. USA 109, 728-732 (2012).

30. A. Tajika, A. Nützel, C. Klug, The old and the new plankton: ecological replacement of associations of mollusc plankton and giant filter feeders after the Cretaceous? PeerJ 6, e4219 (2018).

31. M. J. Henehan, A. Ridgwell, E. Thomas, S. Zhang, L. Alegret, D. N. Schmidt, J. W. B. Rae, J. D. Witts, N. H. Landman, S. E. Greene, B. T. Huber, J. R. Super, N. J. Planavsky, P. M. 
Hull, Rapid ocean acidification and protracted Earth system recovery followed the endCretaceous Chicxulub impact. Proc. Natl. Acad. Sci. USA 116, 22500-22504 (2019).

Acknowledgments: We are grateful to M. Fernández Garza who made the specimen accessible for scientific research and supports our paleontological work at Vallecillo. We thank A. H. González González and-J. M. Padilla Gutiérrez for logistic support and access to the Museo del Desierto collection in Saltillo; O. Sanisidro for the lifelike reconstruction of A. milarcae; T. Tomita for information on Megachasma; B. J. Welton for providing Cretomanta teeth; L. Joanny for SEM imaging; and three anonymous reviewers for their insightful comments on the manuscript. Funding: Financial support was provided by a scholarship of the DAAD (57381316 to E.S.S.) and by Géosciences Rennes, UMR CNRS 6118 (to R.V.). Author contributions: W.S. designed the Vallecillo research project. R.V. and W.S. designed the study. M.A.G.G. secured, collected and prepared the specimen. R.V., E.F., E.S.S., and W.S. collected the data and participated in the observation and interpretation of the specimen. C.I. and W.S. provided information on the stratigraphic context, associated invertebrates and age of the specimen. R.V., E.F., E.S.S., and W.S. photographed the specimen. R.V. prepared the figures and wrote the manuscript with input from all authors. Competing interests: The authors declare no competing interests. Data and materials availability: All data are available in the main text and the supplementary materials; the holotype of Aquilolamna milarcae is housed and displayed in the Museo La Milarca in San Pedro Garza García (MMSP), Nuevo León State, Mexico, under Instituto Nacional de Antropología e Historia (INAH) registration number 2544 P.F.17. The teeth of Cretomanta are stored in the paleontological collection of the Geological Institute of the University of Rennes 1 (IGR), Rennes, France. 


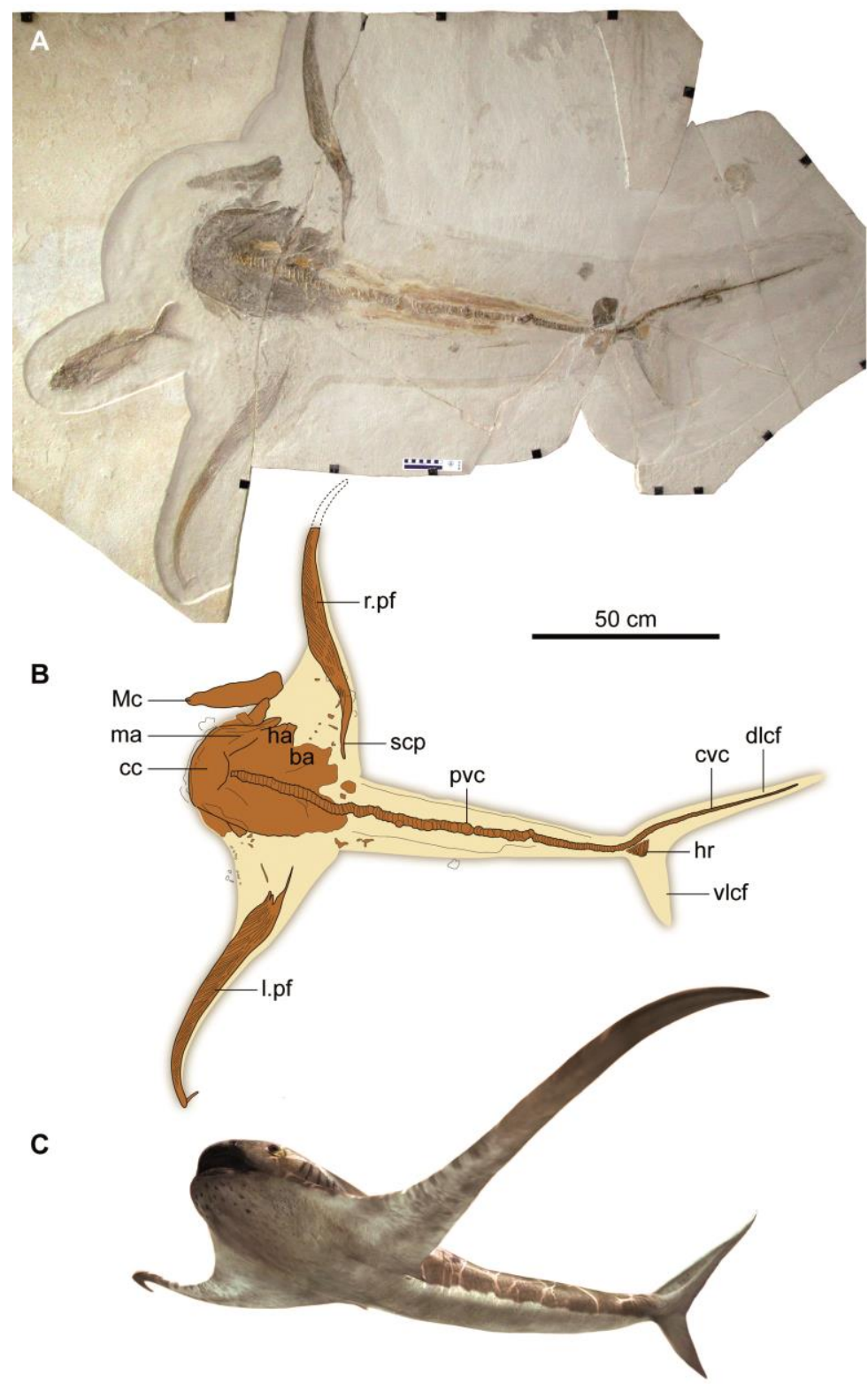

Fig. 1. The holotype and reconstruction of Aquilolamna milarcae. (A) Photograph and (B) interpretative line drawing of the holotype of A. milarcae (INAH 2544 P.F.17). Cartilaginous skeletal elements are shown in brown, and outline based on preserved soft tissue imprints in beige. ba, branchial arches; cc, chondrocranium; cvc, caudal vertebral column; dlcf, dorsal lobe of the caudal fin; ha, hyoid arch; hr, hypochordal rays; 1.pf, left pectoral fin; ma, mandibular arch; Mc, Meckel's cartilage; r.pf, right pectoral fin; pvc, precaudal vertebral column; scp, scapular process; vlcf, ventral lobe of the caudal fin. (C) Life reconstruction of A. milarcae. 

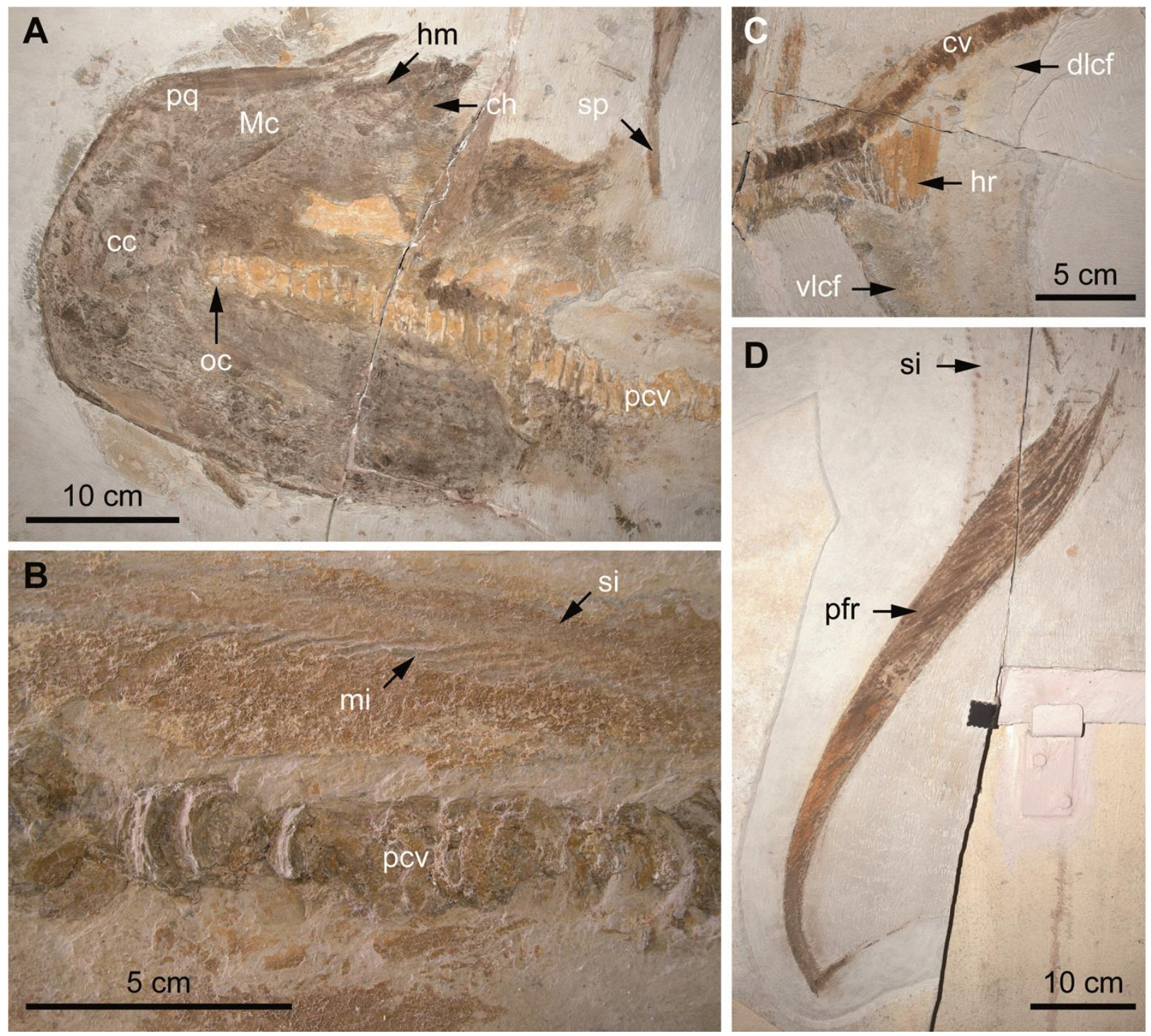

Fig. 2. Anatomical details of Aquilolamna milarcae. (A) Cephalic region. (B) Trunk region.

(C) Caudal region. (D) Left pectoral fin. ch, ceratohyal; cv, caudal vertebrae; hm, hyomandibula; mi, muscle imprint; oc, occipital centrum; pcv, precaudal vertebrae; pfr, pectoral fin radials; pq, palatoquadrate; si, skin imprint; sp, scapular process. 


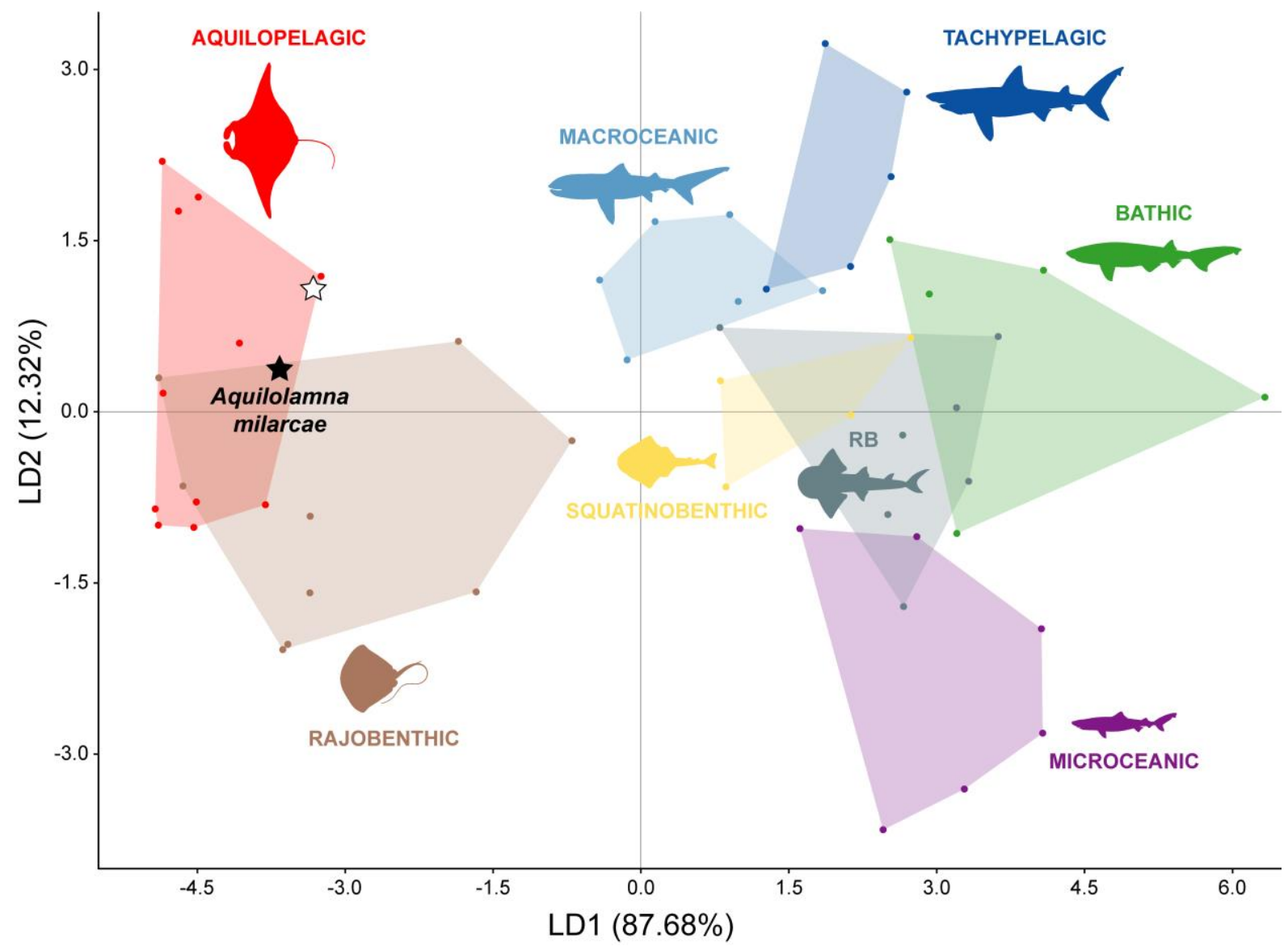

Fig. 3. Ecomorphotype of Aquilolamna milarcae. Linear discriminant (LD) analysis based on log-transformed precaudal length (or disc length) and pectoral fin span (or disc width) measurements for 53 living elasmobranch species belonging to eight specialized ecomorphotypes, with Aquilolamna milarcae added. Note the position of A. milarcae (black star), clearly separated from other selachimorph taxa and suggesting an aquilopelagic-like ecomorphotype for this distinctive shark; this is confirmed when a 250-cm hypothetical maximum total length is used for A. milarcae (white star) (see supplementary materials). RB, rhinobenthic; light-blue silhouette, Megachasma pelagios; dark-blue silhouette, Cetorhinus maximus; green silhouette, Hexanchus griseus; purple silhouette, Pseudocarcharias kamoharai; yellow silhouette, Squatina japonica; gray silhouette, Rhina ancylostoma; red silhouette, Mobula birostris; brown silhouette, Pteroplatytrygon violacea. 


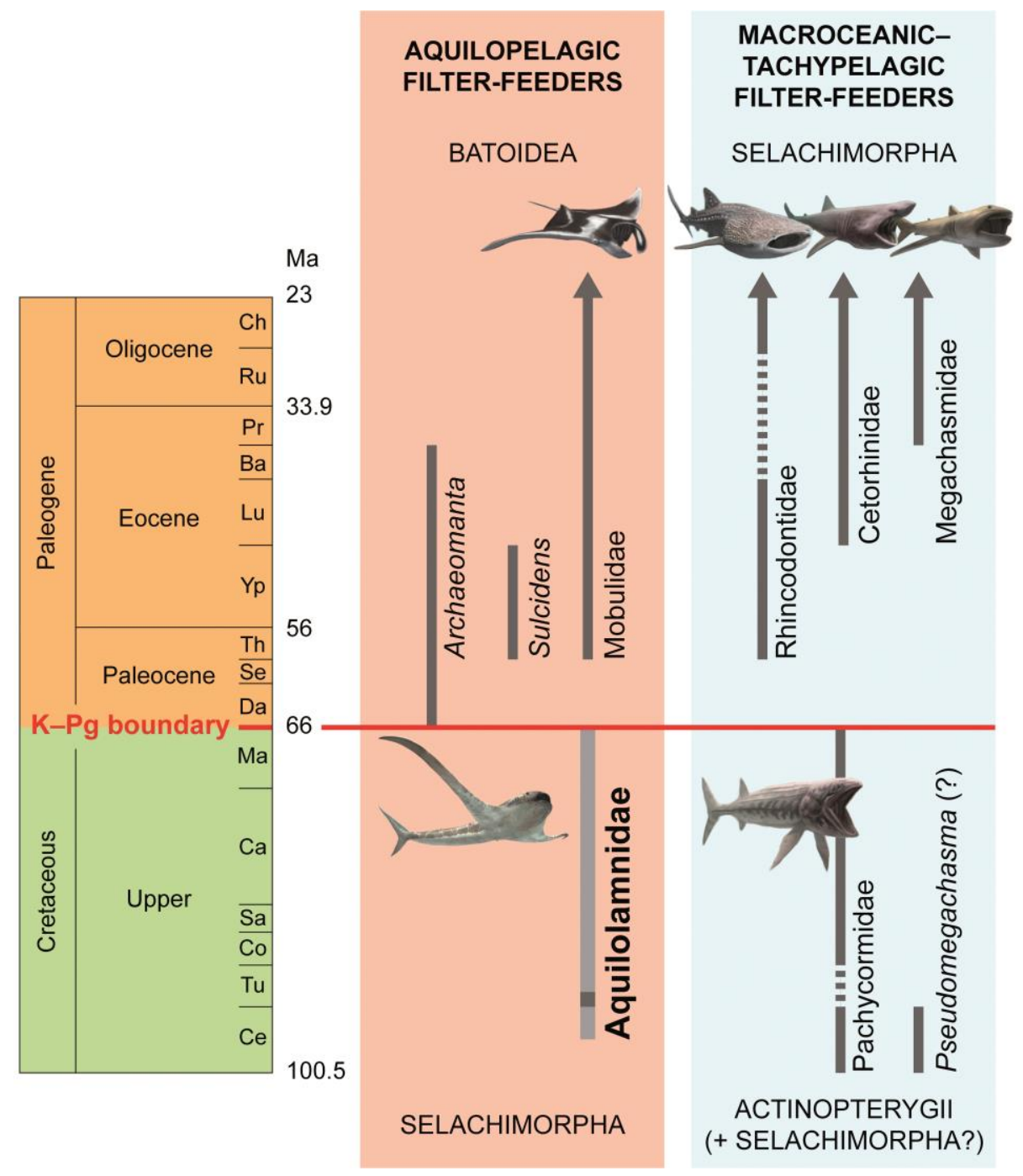

Fig. 4. Aquilopelagic and macroceanic-tachypelagic planktivorous fishes (Neoselachii and Actinopterygii) before and after the Cretaceous-Paleogene boundary. The stratigraphic distribution (Cenomanian-Maastrichtian) of Aquilolamnidae is based on Aquilolamna (dark gray) and known occurrences of the enigmatic genera Cretomanta and Platylithophycus (light gray), two other possible members of the family; arrowed lineages represent still-living groups. Ba, Bartonian; Ca, Campanian; Ce, Cenomanian; Ch, Chattian; Co, Coniacian; Da, Danian; Lu, Lutetian; Ma, Maastrichtian; Pr, Priabonian; Ru, Rupelian; Sa, Santonian; Se, Selandian; Th, Thanetian; Tu, Turonian; Yp, Ypresian. 